\title{
Interaction between Estuarine Microphytobenthos and Physical Forcings: The Role of Atmospheric and Sedimentary Factors
}

\author{
Jerónimo Pan ${ }^{1,2^{*}}$, Constanza N. Bournod ${ }^{2,3}$, Diana G. Cuadrado ${ }^{2,3,4}$, \\ Alejandro Vitale ${ }^{2,3,4}$, María Cintia Piccolo ${ }^{2,3,4}$ \\ ${ }^{1}$ Estación Costera J. J. Nágera, Departamento de Ciencias Marinas, Universidad Nacional de Mar del Plata, \\ Mar del Plata, Argentina \\ ${ }^{2}$ Consejo Nacional de Investigaciones Científicas y Técnicas (CONICET), Argentina \\ ${ }^{3}$ Instituto Argentino de Oceanografía (IADO), Bahía Blanca, Argentina \\ ${ }^{4}$ Universidad Nacional del Sur, Bahía Blanca, Argentina \\ Email: ${ }^{*}$ jeronimopan@gmail.com
}

Received November 8, 2012; revised December 11, 2012; accepted January 15, 2013

\begin{abstract}
The goal of this study was to analyze microbial mats and biofilms from the lower supratidal area of the Bahía Blanca estuary (Argentina), and explore their relationship with sediments and other physical forcings. Thirteen monthly sediment samples (uppermost $10 \mathrm{~mm}$ ) were taken and their composition and abundance in microorganisms was determined by microscopy. Physical parameters (solar radiation and sediment temperature at $-5 \mathrm{~cm}$ ) were recorded with a frequency of 5 minutes by a coastal environmental monitoring station. Additionally, sediment grain size and moisture content were determined for distinct layers in the uppermost $20 \mathrm{~mm}$, and the rate of inundation of the supratidal area was estimated from tidal gauge measurements. There were significant seasonal differences in the biomass of the microphytobenthic groups considered (filamentous cyanobacteria and epipelic diatoms), with the former consistently making up $>70 \%$ of the total biomass. The relationships between microphytobenthos and sediment temperature and solar radiation fitted to linear regressions, and consistently showed an inverse relationship between microphytobenthic abundance and either one of the physical parameters. The granulometric analysis revealed a unimodal composition of muddy sediments, which were vertically and spatially homogeneous; additionally, there were significant seasonal differences in water content loss with drying conditions prevailing in the summer. Several Microbially-Induced Sedimentary Structures (MISS) were identified in the supratidal zone such as shrinkage cracks, erosional pockets, gas domes, photosynthetic domes, mat chips and sieve-like surfaces. In contrast to studies from analogous environments in the Northern Hemisphere, we found reduced microphytobenthic biomass in summer, which were explained by increased evaporation/desiccation rates as a consequence of increased radiation, despite frequent tidal inundation. In conclusion, the observed density shifts in the benthic microbial communities are attributable to physical forcings dependent upon seasonal variations in interplaying factors such as sediment temperature, solar radiation and tidal inundation.
\end{abstract}

Keywords: Biofilms; Microbial Mats; Tidal Flat; Solar Radiation; Sediment Grain Size

\section{Introduction}

Populations of photo-autotrophic microorganisms, collectively known as microphytobenthos, often develop in intertidal and lower supratidal zones, becoming the most important primary producers $[1,2]$. The microphytobenthos consists of unicellular eukaryotic algae and cyanobacteria that grow within the upper several millimeters of illuminated sediments [3]. Hence, this is a zone of intense microbial and geochemical activity and of considerable physical reworking [3]. Due to its influence in

*Corresponding author. sediment stabilization, the microphytobenthos constitutes an important biogeomorphological force [4].

Microphytobenthic organisms may produce macroscopically-recognizable microbial mats dominated by cyanobacteria, or visible biofilms of epipelic diatoms. The community structure is determined by physical parameters such as temperature, light, physical resuspension, and in turn, the biogeochemical activity of the microorganisms determines some sedimentary properties. For example, these organisms secrete large amounts of Extracellular Polymeric Substances (EPS), which are known to aid in their vertical migration $[5,6]$ in response 
to light and tidal conditions [7]. In turn, EPS bind sediment particles together and they can form a smooth layer on the sediment surface [8]. The living microorganisms also influence the surrounding geochemical micro-environment within the sediment, e.g. causing a modification in $\mathrm{pH}$ and inducing authigenic mineral precipitation [9]. Authigenic minerals conserve the morphology of tidal flats creating rigid structures which eventually can be preserved in the geological record $[10,11]$.

The capacity of microphytobenthos to biostabilize sediments in low-energy environments [4] often creates characteristic sedimentary structures termed Microbially-Induced Sedimentary Structures (MISS) [12], which can be preserved in the geological record. Microbial mat deposits were first identified in sandstones and mudstones several decades ago [13]. In recent years, several studies have addressed the interaction between physical, biological and sedimentological processes in modern environments, with the purpose of inferring and interpreting similar processes in the geologic record.

The goal of this study was to explore the relationship between microphytobenthos, sediments and physical factors in a siliciclastic tidal flat colonized by microbial mats in the Bahía Blanca estuary. We relate the seasonal changes in atmospheric and physical variables to the biotic components of microbial mats, with the aim of characterizing the resulting sedimentary structures.

\section{Materials and Methods}

\subsection{Study Area}

Puerto Rosales $\left(38^{\circ} 55^{\prime} \mathrm{S} ; 62^{\circ} 03^{\prime} \mathrm{W}\right)$ is located on the northern margin of the central zone of the Bahía Blanca estuary, Buenos Aires Province, Argentina (Figure 1). The estuary is categorized as mesotidal [14]; semi-diurnal tides predominate and the average tidal amplitude is
2.5 - $3.4 \mathrm{~m}$ during neap and spring tides, respectively. Freshwater input is low; Sauce Chico River (with a drainage area of $1,600 \mathrm{~km}^{2}$ ) outflows into the inner area, and Napostá Grande stream (with a drainage area of 920 $\mathrm{km}^{2}$ ) outflows into the middle zone of the estuary, with an annual mean discharge of 1.9 and $0.8 \mathrm{~m}^{3} \cdot \mathrm{s}^{-1}$, respectively. However, Sauce Chico River may reach higher runoffs in the fall, with peaks of up to $106 \mathrm{~m}^{3} \cdot \mathrm{s}^{-1}$, coinciding with strong precipitation [15].

A semiarid temperate climate characterizes the area, with a mean annual air temperature of $15.6^{\circ} \mathrm{C}$ (mean temperatures range from $22.7^{\circ} \mathrm{C}$ in January to $8.1^{\circ} \mathrm{C}$ in July). Surface seawater mean annual temperature at Puerto Rosales is $14.1^{\circ} \mathrm{C}$. On average, cumulative solar radiation in a cloudless day is $28 \mathrm{MJ} \cdot \mathrm{m}^{-2}$ in summer and $11 \mathrm{MJ} \cdot \mathrm{m}^{-2}$ in winter [16].

In Puerto Rosales, extensive tidal flats ( $1000 \mathrm{~m}$ wide) with low slopes $\left(\sim 0.4^{\circ}\right.$ gradient $)$ are composed of sandy to muddy siliciclastic sediments. Siliciclastic grains predominantly consist of quartz with minor amounts of feldspars. The supratidal area is flooded by seawater, reaching $\sim 10 \mathrm{~cm}$ depths during spring high tides. Local winds from SW to NE sectors generate waves with short wavelengths and $<6 \mathrm{~s}$ periods. The significant wave height in Puerto Rosales is $0.3 \mathrm{~m}$ [17]. Wind velocity presents maximum values in summer and minimum velocities in fall and winter; the monthly mean velocity ranges between $15.9 \mathrm{~km} \cdot \mathrm{h}^{-1}$ and $32 \mathrm{~km} \cdot \mathrm{h}^{-1}$ [18]. The sampling site considered in this study, was located in the lower supratidal area of Puerto Rosales. The cordgrass Spartina alterniflora colonizes the intertidal zone producing wave attenuation, dissipating the hydraulic energy and absorbing wave energy [19], thus reducing the capability of currents to erode and transport sediments [20]. This vegetation shield protects the sampling site from deposition or erosion, promoting a low sedimentation

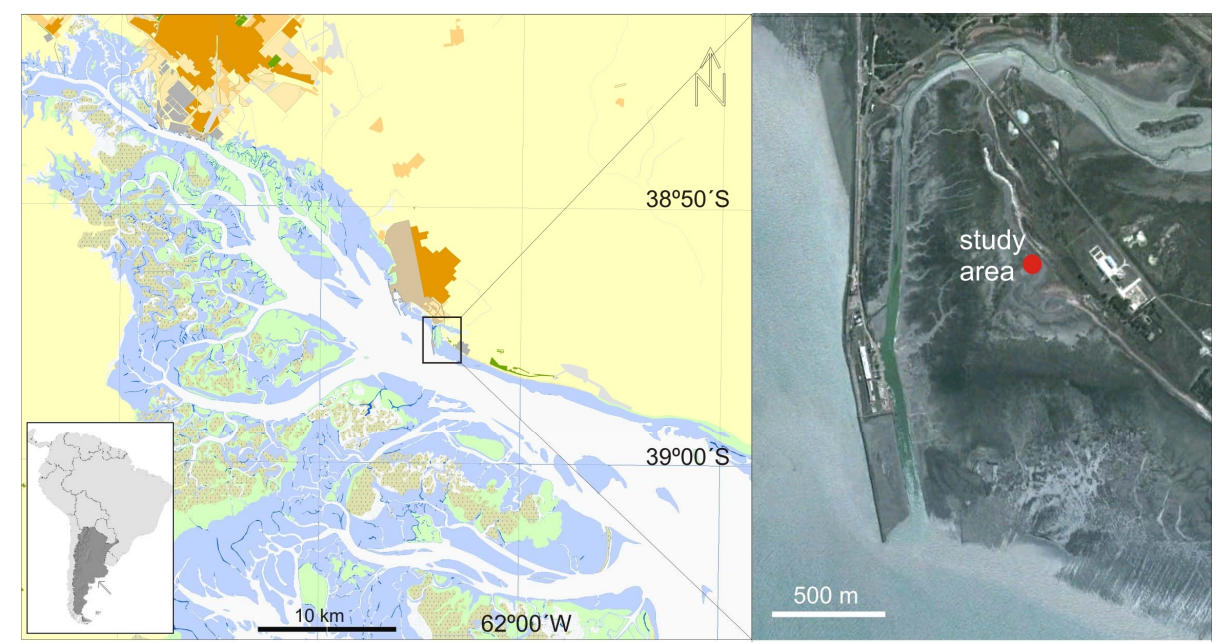

Figure 1. Study area, Puerto Rosales $\left(38^{\circ} 55^{\prime} \mathrm{S}-6^{\circ} 03^{\prime} \mathrm{W}\right)$, located within the Bahía Blanca estuary, Argentina. The inset provides a satellite image, detailing the location of the study site in the supratidal region. 
rate and favoring the colonization of benthic microbial communities that form biofilms and microbial mats [21]. Sediments are disturbed in some patches by macrozoobenthos (the crab Neohelice granulata), which in this site appears to be restricted to vegetated substrates (i.e. Spartina alterniflora and Sarcocornia ambigua).

\subsection{Sampling}

Thirteen sampling events of the microphytobenthos were carried out (dates specified as Julian days on Figure 2). Sampling was consistently done during daytime hours, at low tide. For compositional quantification and enumeration of microorganisms, sediment samples $(n=2)$ were taken with a plastic cylindrical corer (inner diameter $=6$ $\mathrm{mm}$, height $=10 \mathrm{~mm}$ ) and preserved in $50 \mathrm{ml}$ of $5 \%$ acidic Lugol's iodine solution (stock solution prepared with natural filtered seawater). In order to disassemble the microbial mat matrix and enhance contact of the preservative with the microorganisms, the samples were homogenized in a shaker (Bandelin Sonorex Tk52). 1-ml aliquots of the suspension were taken and diluted by addition of $9 \mathrm{ml}$ of $0.45 \mu \mathrm{m}$ filtered seawater. An aliquot of this final suspension was mounted onto a SedgewickRafter counting chamber, and analyzed with a Nikon Eclipse (DIC 600×) microscope [22]. Taxa were classified into the following taxonomic groups: filamentous cyanobacteria, and centric and pennate diatoms. Addi- tionally, standard measurements of cell linear dimensions were performed on 30 specimens of each group, for biovolume estimations [23].

Physical parameters (i.e., solar radiation and sediment temperature) were recorded by means of a coastal environmental monitoring station (EMAC after its initials in Spanish; http://emac.criba.edu.ar/). The EMAC station, placed in situ at Puerto Rosales, is equipped with an APOGEE SP-110 radiation sensor $\left(\mathrm{W} \cdot \mathrm{m}^{-2}\right)$ located $3 \mathrm{~m}$ above the sediment surface. The temperature sensors (developed by $\mathrm{A}$. Vitale) with a recording range from $-15^{\circ} \mathrm{C}$ to $60^{\circ} \mathrm{C}$ and $0.1^{\circ} \mathrm{C}$ resolution (error $+0.1^{\circ} \mathrm{C}$ ) were placed 5, 15 and $30 \mathrm{~cm}$ into the sediment. All sensors have a measuring frequency of 5 minutes.

A discrete number of samples (sediment cores) were taken using sawn-off 50-ml medical syringes, and separated into three layers (layer thickness ranging from 4 to $10 \mathrm{~mm}$ ). Sediment grain size was determined for each layer with a laser diffraction particle analyzer Malvern Mastersizer 2000, for particles in the 0.2 - $2000 \mu \mathrm{m}$ range (i.e. colloids to sand). Organic matter was oxidized prior to the analysis by adding $\mathrm{H}_{2} \mathrm{O}_{2}$ with heating and stirring. Additionally, sediment samples $(n=3)$ were obtained to determine moisture content in June and December, in order to evaluate the extent of desiccation on the tidal flat during the Austral winter and summer. Sediment moisture was calculated from weight differences before and after drying samples at $60^{\circ} \mathrm{C}$ to a constant weight for $96 \mathrm{~h}[24]$.

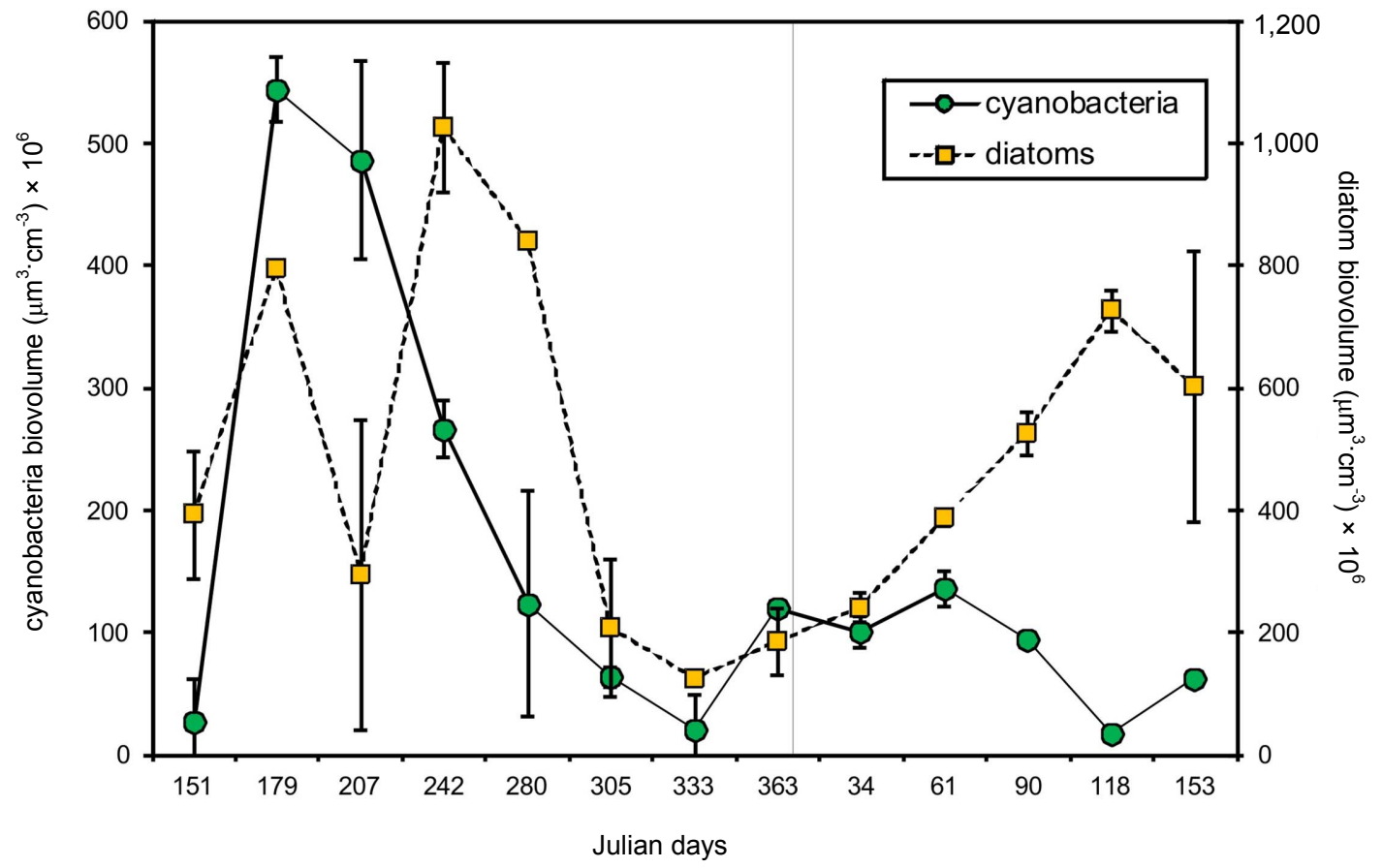

Figure 2. Seasonal variation in microphytobenthos biovolume at Puerto Rosales. Values reported are means $\pm \mathrm{SE}(\mathrm{n}=2)$ for each taxon (cyanobacteria and diatoms). Two-factor ANOVA showed significant differences between taxa $(p<0.001)$ and dates of sampling $(p<0.001)$. 


\subsection{Data Analysis}

Seasonal differences in diatom and cyanobacteria biomass were tested by means of a two-factor ANOVA, with replication [25], with sampling date and taxonomic group as factors. The relationship between diatom and cyanobacteria biomass, and sediment temperature and solar radiation was analyzed by means of linear regressions. For both cases, sediment temperature and solar radiation were considered as the independent variables and were calculated as the mean of all values registered 24-h before sampling for microphytobenthos. The significance of linear regressions was tested by means of ANOVA [25]. Additionally, the correlation of the independent versus dependent datasets was tested. The statistical parameters used to describe grain size distribution were calculated with GRADISTAT software [26]. The differences in sediment moisture content were tested by means of a two-factor ANOVA, with replication [25], with season and sediment layer as factors.

\section{Results}

\subsection{Qualitative Analysis of the Microphytobenthic Community}

The microphytobenthic community integrating biofilms and microbial mats $(10 \mathrm{~mm}$ in depth) consisted in unicellular (epipelic diatoms) and filamentous microalgae (cyanobacteria). The smaller pennate diatoms $(<40 \mu \mathrm{m})$ included the genera Diploneis, Nitzschia and Navicula, while the larger-sized representatives included species of the latter two genera, and also the species Gyrosigma spencerii and Cylindrotheca closterium. Centric diatoms included the genera Thalassiosira, Coscinodiscus and Melosira. All cyanobacteria found in the sediments were non-heterocystous, with Microcoleus chthonoplastes being the dominant species, and the genera Oscillatoria and Arthrospira being also present.

\subsection{Quantitative Analysis of the Microphytobenthic Community}

There were significant differences in the biomass (expressed as cell biovolume) of the two groups of microphytobenthos considered [two-factor ANOVA, F $(1,51)$ $=21.79 ; \mathrm{p}<0.001]$ (Figure 2). The biomass of cyanobacteria was consistently larger than that of diatoms, by 1 or 2 orders of magnitude, making up $>70 \%$ of the total biomass on all dates. Cyanobacteria, presented their highest biomass in winter, and with the exception of the lower values registered on Julian day 207, diatom biomass had a similar pattern, peaking from late fall (Julian day 151) into early spring (Julian day 280).These seasonal differences in biomass were statistically significant [two-factor ANOVA, F $(12,51)=224.03 ; \mathrm{p}<0.001]$.

\subsection{Relationship between Biomass and Physical Parameters}

The relationship between diatom and cyanobacteria biomass, and sediment temperature and solar radiation (SR) was analyzed by means of linear regressions. For both parameters the trends were similar, with inverse relationships between the biomass of either cyanobacteria or diatoms and the environmental parameter. The relationship between cyanobacteria biomass and sediment temperature was fitted to a linear regression (ANOVA, $\mathrm{F}(1$, 12) $=4.96, p<0.05 ; r^{2}=0.31$ ) (Figure 3(a)). Diatom biomass also presented a significant linear relationship with sediment temperature (ANOVA, F $(1,11)=8.76$, $\mathrm{p}$ $<0.01$ ), with a higher correlation $\left(\mathrm{r}^{2}=0.47\right)$ (Figure 3(a)). The linear relationship between cyanobacteria and SR was also significant (ANOVA, F $(1,9)=8.44, p<$ $0.05)$ and presented a high correlation $\left(\mathrm{r}^{2}=0.51\right)$ (Figure 3(b)). Correlation was even higher for diatom biomass and SR $\left(r^{2}=0.65\right)$, and the linear regression between these datasets was also significant (ANOVA, F $(1,10)=$ 16.7, $\mathrm{p}<0.01$ ) (Figure 3(b)).

Averaged sediment temperature (measured at $-5 \mathrm{~cm}$ ) ranged from $5.3^{\circ} \mathrm{C}$ on $6 / 28 / 2011$ (Austral winter; coinciding with the maximum biomass registered for cyanobacteria, see Figure 2) to $27.7^{\circ} \mathrm{C}$ on $12 / 29 / 2011$ (Austral summer). A temperature gradient was calculated between sediment layers at -5 and $-15 \mathrm{~cm}$ for winter and summer. On average, the gradient was $0.4^{\circ} \mathrm{C} \cdot \mathrm{cm}^{-1}$ in winter and $1.1^{\circ} \mathrm{C}^{\cdot} \mathrm{cm}^{-1}$ in summer, i.e., a 3-fold variation between seasons. Averaged SR (measured $3 \mathrm{~m}$ above the sediment surface) ranged from $71.8 \mathrm{~W} \cdot \mathrm{m}^{-2}$ on $6 / 28 / 2011$ to 322.8 $\mathrm{W} \cdot \mathrm{m}^{-2}$ on $11 / 29 / 2011$ (late Austral spring).

\subsection{Grain Size and Moisture Content}

The granulometric analysis revealed a unimodal composition of the muddy sediments at the study site, which was vertically and spatially homogeneous (Figure 4(a)). The sediment was dominated by medium to coarse silt (mode $=23.3 \mu \mathrm{m})$, and a variable clay content ranging between $20 \%-30 \%$. The grain size distribution of each layer in the tidal flat profile (uppermost $20 \mathrm{~mm}$ ) is shown in Figure 4(b). The green/brownish upper layer $(1 \mathrm{~mm}$ thick) corresponded to a biofilm. Lamination and a black reduced horizon (usually located $3 \mathrm{~mm}$ deep) were often visible (Figure 4(a)). Statistical parameters obtained for the seasonal sediment samples show that sediment at this site is very poorly sorted, very fine skewed (with an excess of fine fractions) and meso- to leptokurtic. Sediment moisture in the uppermost $10 \mathrm{~mm}$ layer ranged between $22.4 \mathrm{wt} \%-44.5 \mathrm{wt} \%$.

Water content measurements during emersion in winter and summer conditions resulted in greater values on winter, with minor differences of water content $(<1 \%)$ 
(a)

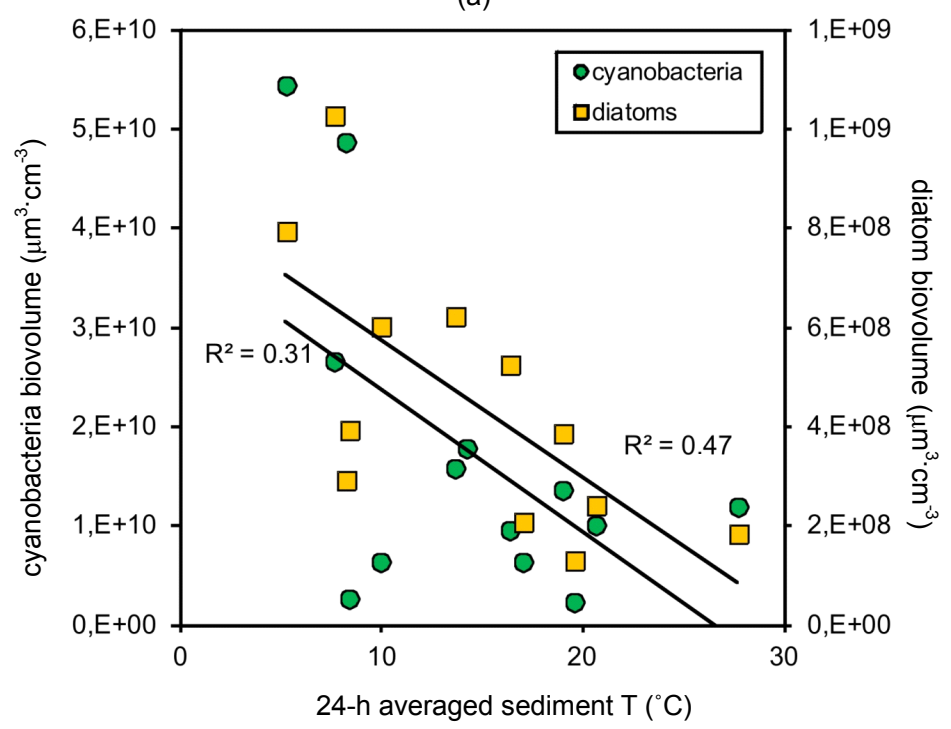

(b)

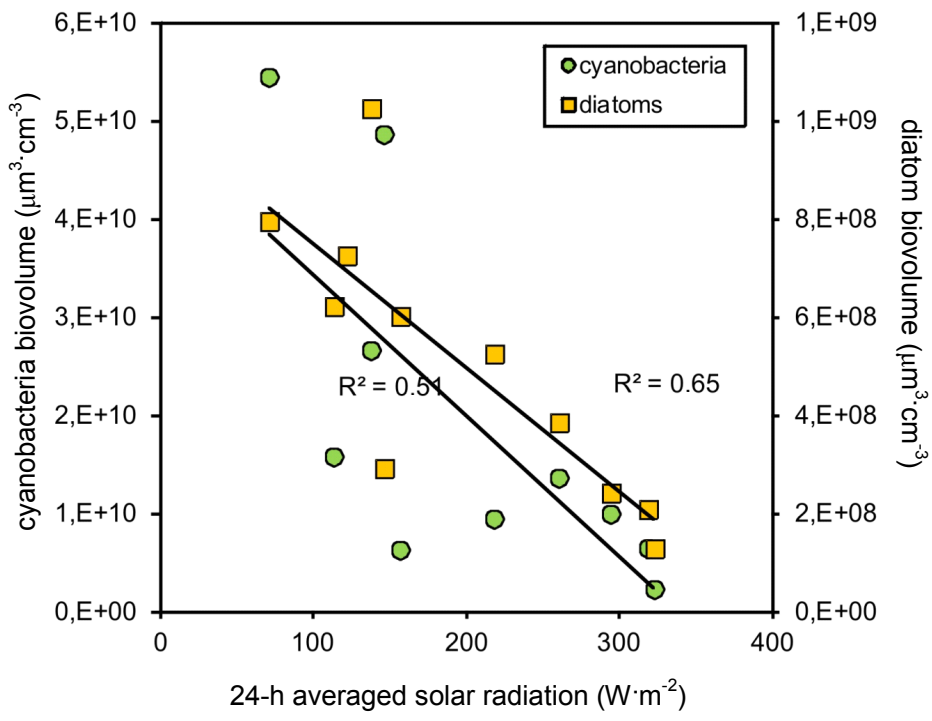

Figure 3. Relationship between cyanobacteria and diatom biomass, and (a) sediment temperatue ( $-5 \mathrm{~cm}$, averaged over a $24 \mathrm{~h}$ period). Data fitted to linear regressions and significance tested by means of ANOVA $\left(r^{2}=0.31, p<0.05\right.$ for cyanobacteria; $r^{2}$ $=0.47, \mathrm{p}<0.01$ for diatoms); and (b) solar radiation ( $3 \mathrm{~m}$ above sediment surface, averaged over a $24 \mathrm{~h}$ period). Data fitted to linear regressions and significance tested by means of ANOVA $\left(r^{2}=0.51, p<0.05\right.$ for cyanobacteria; $\mathbf{r}^{2}=0.65, p<0.01$ for diatoms).

lost on the upper layers, while summer evidenced overall drying conditions (Figure 4(c)). These seasonal differences in water content loss were statistically significant [two-factor ANOVA, F $(1,17)=63.00 ; p<0.001]$. The upper layers lost between $2 \%-5 \%$ of water with a steady increase in temperature during sampling time.

\subsection{Microbially-Induced Sedimentary Structures}

Several MISS were identified in the supratidal zone of the tidal flat, among which the most conspicuous are: shrinkage cracks, erosional pockets, gas domes, photosynthetic domes, mat chips and sieve-like surfaces.

Shrinkage cracks constitute mat-destruction structures formed due to subaerial exposure and desiccation of the mats, typical of supratidal areas [11], where the upper surface of the mat undergoes greater contraction than the underlying layers (Figure 5(a)). They commonly start as sigmoidal spindle-shaped cracks which are not connected to each other, but once they join, they form subcircular, triradiate or triple-junction patterns (Figure 5(b)), evolving into a more or less complete network. The 

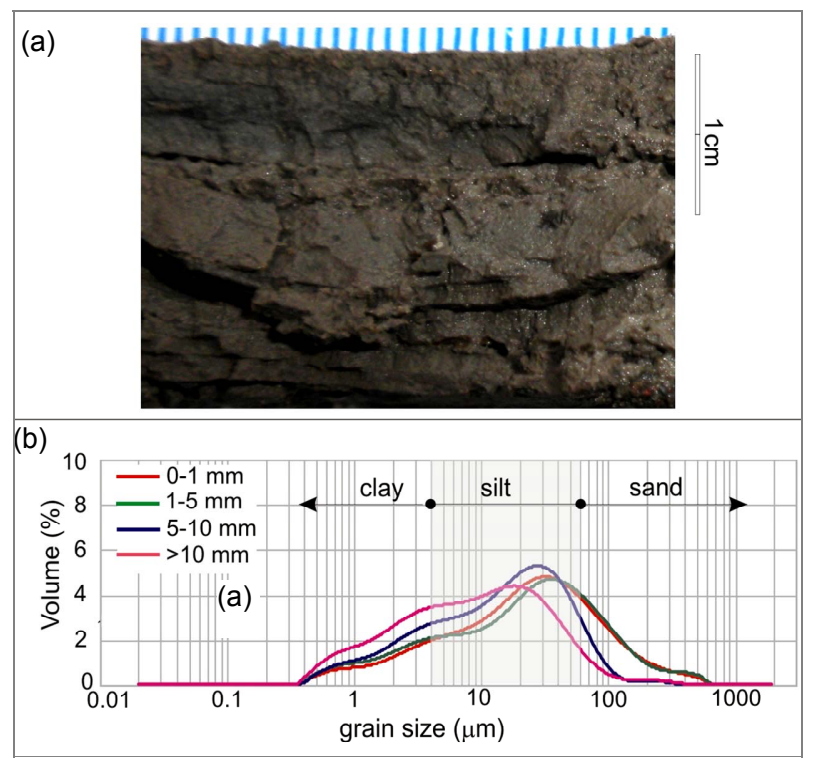

(c)

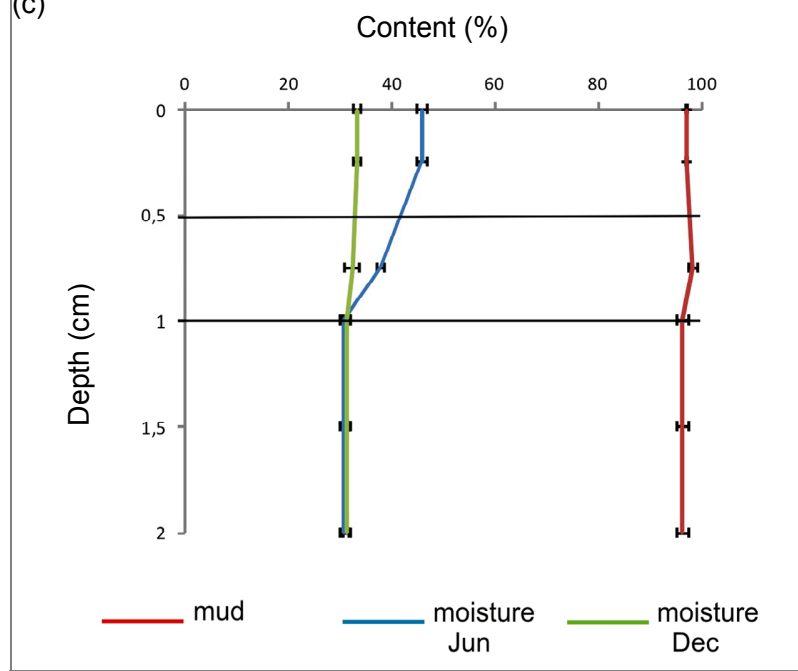

Figure 4. Grain size and moisture content for the topmost 2 cm of sediment at Puerto Rosales. (a) Cross section showing characteristic layering of surface sediments; (b) Granulometric analysis showing dominance of mud particles at all sediment layers; (c) Moisture retention and mud content (\%) throughout the sediment profile; values are means $\pm \mathrm{SE}$ $(\mathbf{n}=3)$.

irregular pattern of the cracks network defines polygons with a variety of sizes, ranging from about 3 to $30 \mathrm{~cm}$. Sometimes, the edges of the polygons become rounded and curled up, widening the open cracks from 1 to $10 \mathrm{~cm}$ (Figure 5(d)). Typically, open cracks are favorable sites for the new growth of microbes, so when the surface gets wet again mat cracks are overgrown by the newlyformed microbial mats and "healed" (Figure 5(e)). As dry conditions return the cracks open again usually following the same pathway.

Erosional pockets are derived from the mechanical destruction of the biostabilized sediment surface $[27,28]$.

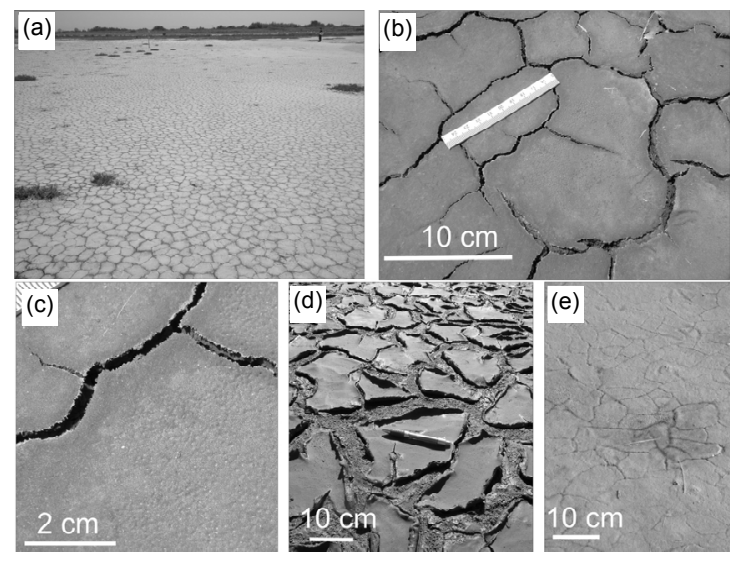

Figure 5. Shrinkage cracks. (a) General aspect of tidal flat, foreground width is $4 \mathrm{~m}$; (b) The microbial mat and its underlying sandy layer react differently to desiccation, creating an initial stage of shrinkage crack with a sinusoidal shape; (c) Close-up of the torn microbial mat, note the sieve-like surface, the product of bursting gas bubbles; (d) Network of wide shrinkage cracks, note the curled-up mat margin created as a tensile strength of the sediment due to filamentous cyanobacteria [46]; (e) Cracks are overgrown by new biofilms and biomass accretion.

These structures evolve from local destruction of the microbial mat that covered the surface sediment during high energy conditions, generating irregular-shaped depressions [27] (Figure 6(a)).

Gas domes occur when the gases trapped beneath the relatively impermeable microbial film accumulate, increasing the pressure and pushing the mat upward, producing a bulge and a hollow cavern underneath [11]. Its formation requires gas production underneath or within the mat which involves organic matter decay, and also an impermeable sealing-mat (Figure 6(b)). Each gas dome can last several days.

Photosynthetic domes are small domes formed by deformation of the elastic surface layer due to accumulation of oxygen released as a product of photosynthesis by underlying cyanobacteria [29]. Eventually, they dominate the surface morphology and the resulting feature is called "blister mat" (Figure 6(c)).

Sieve-like surfaces are the product of numerous tiny surface pits created by the impressions of biostabilized photosynthetic gas bubbles formed on the mat surface [30]. The depth of each pit oscillates between $1-2 \mathrm{~mm}$ and their diameters range up to $\sim 1 \mathrm{~mm}$ (Figures 5(c) and 6(d)).

Microbial mat chips are sedimentary features related to the physical mat-destruction that comprise eroded mat fragments, which reflect reworking and transport (Figure 6(e)). Chips are irregularly shaped, flat-planar, often with rounded edges, and with flexible-cohesive behavior. These mat-chips are 1 to several $\mathrm{cm}$ long and they are commonly seen spread all over the lower supratidal flat after storm events. 

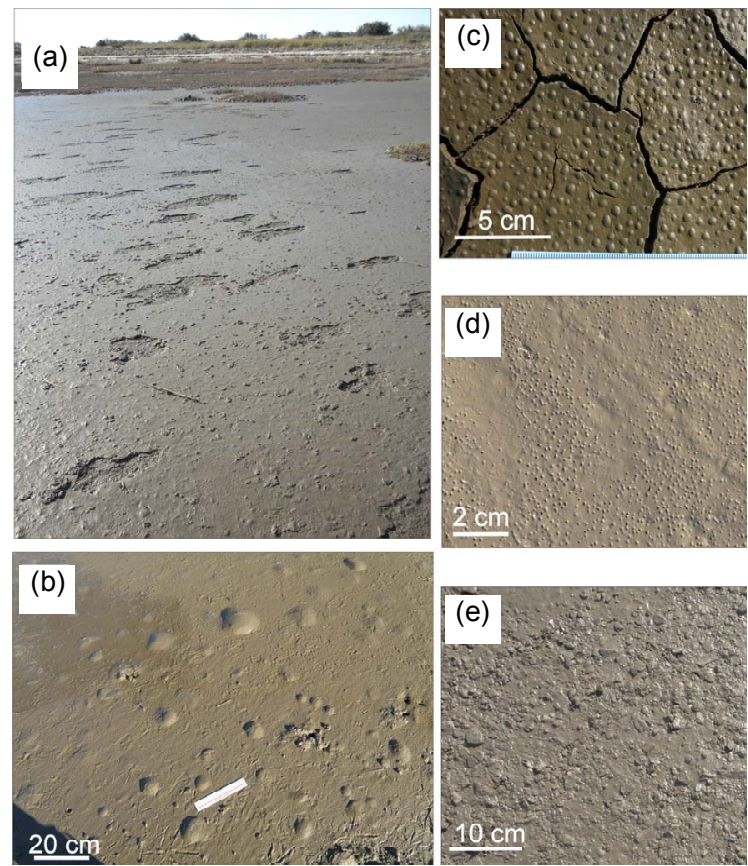

Figure 6. Microbially-Induced Sedimentary Structures. (a) Erosional pockets; (b) Gas domes; (c) Photosynthetic domes; (d) Sieve-like surface; (e) Microbial mat chips. See text for details.

\section{Discussion}

Microbial mats that develop in the supratidal zone of estuarine sediments have been termed "epibenthic mats" [11]. The dominance of cyanobacteria in the epibenthic mats of Puerto Rosales, and in particular the species Microcoleus chthonoplastes, which has many trichomes threaded into a spiral arrangement resulting in a mesh of interweaving cyanobacterial filaments, has been pointed to be indicative of a well-developed microbial mat [31]. The architecture of cyanobacteria filaments proper, and the secretion of EPS interplay and they generate a more efficient entanglement of sediment grains than in a diatom biofilm [32]. This, in turn translates into an established critical biomass of cyanobacteria which does not present biomass fluctuations as marked as those of a diatom biofilm.

The Bahía Blanca estuary, is a typical temperate estuary (sediment temperature ranges between $5.3^{\circ} \mathrm{C}$ and $27^{\circ} \mathrm{C}$ and SR between 72 to $323 \mathrm{~W} \cdot \mathrm{m}^{-2}$ ), that shows no evidence of extreme physical forcings, that might hinder the development of microbial mats and biofilms throughout the year in contrast to what has been reported for estuarine systems in the Northern Hemisphere. However, the inverse relationships between microphytobenthic biomass and temperature and SR (Figure 3), clearly point to optimal conditions for the establishment of dense populations of cyanobacteria and diatoms, as being in the lower ranges of these two parameters. Accordingly it has been pointed [33] that the temporal distribution of microphytobenthos can be explained partly by the seasonal variation in irradiance and sediment temperature. Studying the influence of different grain sizes and temperatures on the growth of benthic cyanobacteria and diatoms it was found [34] that diatoms achieved the highest biomass on the finest sediments $(<63 \mu \mathrm{m})$, in a temperature range of $10^{\circ} \mathrm{C}-15^{\circ} \mathrm{C}$, while cyanobacteria achieved low biomass levels in the same temperature range. However, with progressively higher temperatures (reaching up to $25^{\circ} \mathrm{C}$ ), cyanobacteria outcompeted diatoms, and the grain size factor was overruled by temperature effects, which controlled the growth of cyanobacteria. Conversely, in our field study, we found the highest cyanobacteria biomass when sediment temperature was low $\left(5.3^{\circ} \mathrm{C}\right.$ on 6/28/2011; Figure 2), and the density pattern of diatoms closely followed that of cyanobacteria. This and previous studies carried out in the Bahía Blanca estuary [35], in which microbial mat populations of cyanobacteria and diatom show peak abundances in winter and lowest biomass in summer, contrasts with the pattern reported for other temperate locations $[27,36]$.

It is worth mentioning that an annual survey of planktonic production [37] found the highest phytoplanktonic biomass in the Bahía Blanca estuary during winter months, and the abundance of these peaks corresponded to a bloom of planktonic diatoms. We do not have evidence of a link between the peaks in benthic diatoms reported in this study, and the peaks in planktonic species, but it has been established that resuspended microphytobenthos may make a significant contribution to phytoplankton [38].

One plausible explanation for the reduced microphytobenthic biomass in summer lies in the increase in evaporation/desiccation rates in the tidal flat, as a consequence of increased radiation. In our study, average radiation roughly varied 4.5 -fold between winter and the onset of summer, likely creating hypersaline conditions in pore water and making the microorganisms osmotically-stressed, resulting in slowed physiological processes and little growth [39]; but see [40]. On the other hand, tidal height at Puerto Rosales is amplified during spring tides or due to wind conditions. The analysis of tidal heights (from a tidal gauge located $5 \mathrm{~km}$ into the Bahía Blanca estuary from the study site; Figure 7) evidences that the tidal flat at Puerto Rosales was less frequently inundated in winter and spring, compared to summer and fall, due to the prevalence of strong SE winds (see Figure 2 in [41]). Therefore, it seems that despite the higher frequency of supratidal inundation in summer, the effects of desiccation due to increased radiation, adversely affect the development of microphytobenthic communities during this season. The water content of surface sediment decreases due to drainage and 


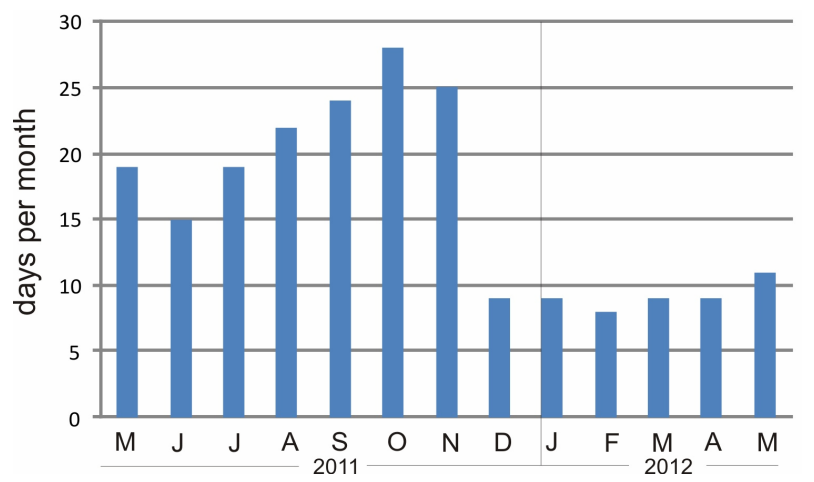

Figure 7. Monthly frequency of tidal flat inundation at Puerto Rosales, based on tidal height data from a tidal gauge located $5 \mathrm{~km}$ into the inner Bahía Blanca estuary from the study site.

evaporation, and this is a cumulativeprocess, with sediments consolidating as water content becomes progresssively lower [42].

Sediment grain size plays a pivotal role in the distribution and abundance of microphytobenthos [34]. In fine estuarine mud, light absorption takes places in a very thin surface layer $(0.14 \mathrm{~mm})$ [43]. Since light is a limiting factor for primary production, benthic photosynthesis in muddy sediments is limited to this very thin photic zone $(<2 \mathrm{~mm})$ [44], which favors microphytobenthos with high migration- and cell division rates (i.e. epipelic diatoms) over other populations.

The study area is characterized by the abundance of cohesive silts in the topmost layers of sediment, which retain high moisture content. The characteristic laminated pattern is a product of the abundance of cyanobacteria and the spatial arrangement of grain sediments produced by these microorganisms [45]. The sedimentary structures recognized for the study area correspond to those typical of a supratidal flat which is sporadically inundated by tides [11]. These structures are the result of the interaction between sediments and physical (e.g. solar radiation, inundation and tidal currents) and biological factors (e.g. community composition of microbial mats and biofilms, EPS secretion), and other physico-chemical processes that precede early diagenesis. Their study in modern environments aids in their recognition in the rock record and for interpretations in paleoenvironmental studies.

\section{Conclusion}

The supratidal flats at Puerto Rosales are composed of cohesive silty sediments that retain moisture. These sediments and the microphytobenthos are continuously affected by sea-air interactive processes. No previous studies on physical-biological interactions were performed for this area. We report significant variations in the biomass of cyanobacteria and epipelic diatoms throughout the year, with maxima in winter, which is in stark contrast to the pattern reported for analogous systems in the Northern Hemisphere. These density shifts are attributable to physical forcings dependent upon seasonal variations in interplaying factors such as sediment temperature, solar radiation and tidal inundation.

\section{Acknowledgements}

This study was funded by Agencia Nacional de Promoción Científica y Tecnológica (PICT 374/07) and Secretaría General de Ciencia y Tecnología-UNS (PGI 24/ $\mathrm{ZH} 20$ ); the former institution supported CNB in the form of a fellowship. JP was partially supported by a Postdoctoral Fellowship from CONICET.

\section{REFERENCES}

[1] J. L. Pinckney and R. Zingmark, "Biomass and Production of Benthic Microalgal Communities in Estuarine Habitats," Estuaries, Vol. 16, No. 4, 1993, pp. 887-897. doi: $10.2307 / 1352447$

[2] V. Cariou-Le Gall and G. H. Blanchard, "Monthly HPLC Measurements of Pigment Concentration from an Intertidal Muddy Sediment of Marennes-Oleron Bay, France," Marine Ecology Progress Series, Vol. 121, 1995, pp. 171179. doi:10.3354/meps 121171

[3] H. L. MacIntyre, R. J. Geider and D. C. Miller, "Microphytobenthos: The Ecological Role of the 'Secret Garden' of Unvegetated, Shallow-Water Marine Habitats. Distribution, Abundance and Primary Production," Estuaries, Vol. 19, No. 2, 1996, pp. 186-201. doi: $10.2307 / 1352224$

[4] L. J. Stal, "Microphytobenthos as a Biogeomorphological Force in Intertidal Sediment Stabilization," Ecological Engineering, Vol. 36, No. 2, 2010, pp. 236-245. doi:10.1016/j.ecoleng.2008.12.032

[5] D. M. Paterson, "Short Term Changes in the Erodibility of Intertidal Cohesive Sediments Related to the Migratory Behaviour of Epipelic Diatoms," Limnology and Oceanography, Vol. 34, No. 1, 1989, pp. 223-234. doi:10.4319/10.1989.34.1.0223

[6] D. J. Smith and G. J. C. Underwood, "Exopolymer Production by Intertidal Epipelic Diatoms," Limnology and Oceanography, Vol. 43, No. 7, 1998, pp. 1578-1591. doi:10.4319/10.1998.43.7.1578

[7] S. J. Hay, T. C. Maitland and D. M. Paterson, "The Speed of Diatom Locomotion through Natural and Artificial Substrata," Diatom Research, Vol. 8, No. 2, 1993, pp. 371-384. doi:10.1080/0269249X.1993.9705268

[8] D. M. Paterson, R. M. Crawford and C. Little, "Subaerial Exposure and Changes in the Stability of Intertidal Estuarine Sediments," Estuarine Coastal and Shelf Science, Vol. 30, No. 6, 1990, pp. 541-556. doi:10.1016/0272-7714(90)90091-5

[9] M. Merz, "Calcification in Cyanobacteria," In: R. Riding and S. Awramik, Eds., Microbial Sediments, Springer Verlag, Berlin, 2000, pp. 50-56. 
[10] A.W. Decho, "Overview of Biopolymer-Induced Mineralization: What Goes on in Biofilms?" Ecological Engineering, Vol. 36, No. 2, 2010, pp. 137-144. doi:10.1016/i.ecoleng.2009.01.003

[11] N. Noffke, "Microbial Mats in Sandy Deposits from the Archean Era to Today," Springer-Verlag, Berlin, 2010.

[12] N. Noffke, G. Gerdes, T. Klenke and W. E. Krumbein, "Microbially Induced Sedimentary Structures-A New Category within the Classification of Primary Sedimentary Structures," Journal of Sedimentary Research, Vol. 71, No. 5, 2001, pp. 649-656. doi:10.1306/2DC4095D-0E47-11D7-8643000102C1865 D

[13] J. Schieber, "The Possible Role of Benthic Microbial Mats during the Formation of Carbonaceous Shales in Shallow Proterozoic Basins," Sedimentology, Vol. 33, No. 4, 1986, pp. 524-536. doi:10.1111/j.1365-3091.1986.tb00758.x

[14] M. O. Hayes, "Barrier Island Morphology as a Function of Tidal and Wave Regime," In: S. Leatherman, Ed., Proceedings of the Coastal Symposium of Barrier Islands, New York Academic Press, New York, 1979, pp. 1-28.

[15] M. C. Piccolo, G. M. E. Perillo and J. M. Arango, "Hidrografía del Estuario del Río Sauce Chico (Bahía Blanca)," Geoacta, Vol. 17, 1990, pp. 13-23.

[16] D. Beigt, "Balance Energético de las Planicies de Marea del Estuario de Bahía Blanca," Ph.D. Dissertation, Universidad Nacional del Sur, Bahía Blanca, 2006.

[17] Nedeco-Arconsult, "Estudio del Dragado del Canal de Acceso al Puerto de Bahía Blanca," Final Technical Report, Bahía Blanca, 1983.

[18] M. C. Piccolo and P. G. Diez, "Meteorología del Puerto Coronel Rosales," In: M. C. Piccolo and M. Hoffmeyer, Eds., Ecosistema del Estuario de Bahía Blanca, UNS, Bahía Blanca, 2004, pp. 87-90.

[19] E. W. Koch, E. B. Barbier, B. R. Silliman, D. J. Reed, G. M. Perillo, S. D. Hacker, E. F. Granek, J. H. Primavera, N. Muthiga, S. Polasky, B. S. Halpern, C. J. Kennedy, C. V. Kappel and E. Wolanski, "Non-Linearity in Ecosystem Services: Temporal and Spatial Variability in Coastal Protection," Frontiers in Ecology and the Environment, Vol. 7, No. 1, 2009, pp. 29-37. doi:10.1890/080126

[20] E. Wolanski, M. M. Brinson, D. R. Cahoon and G. M. E Perillo, "Coastal Wetlands: A Synthesis," In: G. M. E. Perillo, E. Wolanski, D. R. Cahoon and M. M. Brinson, Eds., Coastal Wetlands: An Integrated Ecosystem Approach, Elsevier, Amsterdam, 2009, pp. 1-62.

[21] D. G. Cuadrado, N. B. Carmona and C. Bournod, "Biostabilization of Sediments by Microbial Mats in a Temperate Siliciclastic Tidal Flat, Bahía Blanca Estuary (Argentina)," Sedimentary Geology, Vol. 237, No. 1-2, 2011, pp. 95-101. doi:10.1016/j.sedgeo.2011.02.008

[22] M. LeGresley and G. McDermott, "Counting Chamber Methods for Quantitative Phytoplankton Analysis: Haemocytometer, Palmer-Maloney Cell and Sedgewick-Rafter Cell," In: B. Karlson, C. Cusack and E. Bresnan, Eds., Microscopic and Molecular Methods for Quantitative Phytoplankton Analysis, IOC Manuals and Guides No. 55, UNESCO, Paris, 2010, pp. 25-30.
[23] J. Sun and D. Liu, "Geometric Models for Calculating Cell Biovolume and Surface Area for Phytoplankton," Journal of Plankton Research, Vol. 25, No. 11, 2003, pp. 1331-1346. doi:10.1093/plankt/fbg096

[24] M. C. Christie, K. R. Dyer, G. Blanchard, A. Cramp, H. J. Mitchener and D. M. Paterson, "Temporal and Spatial Distributions of Moisture and Organic Contents across a Macrotidal Mudflat," Continental Shelf Research, Vol. 20, No. 10-11, 2000, pp. 1219-1241. doi:10.1016/S0278-4343(00)00020-0

[25] J. Zar, "Biostatistical Analysis," 4th Edition, Prentice Hall, Upper Saddle River, 1999.

[26] S. J. Blott and K. Pye, "GRADISTAT: A Grain Size Distribution and Statistics Package for the Analysis of Unconsolidated Sediments," Earth Surface Processes and Landforms, Vol. 26, No. 11, 2001, pp. 1237-1248. doi:10.1002/esp.261

[27] N. Noffke and W. E. Krumbein, "A Quantitative Approach to Sedimentary Surface Structures Contoured by the Interplay of Microbial Colonization and Physical Dynamics," Sedimentology, Vol. 46, No. 3, 1999, pp. $417-$ 426. doi:10.1046/i.1365-3091.1999.00218.x

[28] G. Gerdes, "Structures Left by Modern Microbial Mats in Their Host Sediments," In: J. Schieber, P. K. Bose, P. G. Eriksson, S. Banerjee, S. Sarkar, W. Altermann and O. Catuneanu, Eds., Atlas of Microbial Mat Features Preserved within the Siliciclastic Rock Record, Elsevier, Amsterdam, 2007, pp. 5-38.

[29] P. G. Eriksson, J. Schieber, E. Bouougri, G. Gerdes, H. Porada, S. Benerjee, P. K. Bose and S. Sarkar, "Classification of Structures Left by Microbial Mats in Their Host Sediments," In: J. Schieber, P. K. Bose, P. G. Eriksson, S. Banerjee, S. Sarkar, W. Altermann and O. Catuneanu, Eds., Atlas of Microbial Mat Features Preserved within the Siliciclastic Rock Record, Elsevier, Amsterdam, 2007, pp. 39-52.

[30] S. Bose and H. S. Chafetz, "Topographic Control on Distribution of Modern Microbially Induced Sedimentary Structures (MISS): A Case Study from the Texas Coast," Sedimentary Geology, Vol. 213, No. 3-4, 2009, pp. 136149. doi:10.1016/j.sedgeo.2008.11.009

[31] L. J. Stal, H. van Gemerden and W. E. Krumbein, "Structure and Development of a Benthic Marine Microbial Mat," FEMS Microbiology Ecology, Vol. 31, No. 2, 1985, pp. 111-125. doi:10.1111/j.1574-6968.1985.tb01138.x

[32] B. de Winder, N. Staats, L. J. Stal and D. M. Paterson, "Carbohydrate Secretion by Phototrophic Communities in Tidal sediments," Journal of Sea Research, Vol. 42, No. 2, 1999, pp. 131-146. doi:10.1016/S1385-1101(99)00021-0

[33] W. Admiraal and H. Peletier, "Influence of Seasonal Variations of Temperature and Light on the Growth Rate of Culture and Natural Populations of Intertidal Diatoms," Marine Ecology Progress Series, Vol. 2, 1980, pp. 35-43. doi: $10.3354 / \mathrm{meps} 002035$

[34] F. Watermann, H. Hillebrand, G. Gerdes, W. E. Krumbein and U. Sommer, "Competition between Benthic Cyanobacteria and Diatoms as Influenced by Different Grain Sizes and Temperatures," Marine Ecology Pro- 
gress Series, Vol. 187, 1999, pp. 77-87. doi: $10.3354 / \mathrm{meps} 187077$

[35] J. Pan, C. N. Bournod, N. V. Pizani, D. G. Cuadrado and N. B. Carmona, "Characterization of Microbial Mats from a Siliciclastic Tidal Flat (Bahía Blanca Estuary, Argentina)," Geomicrobiology Journal (In press).

[36] A. Solé, N. Gaju, S. Méndez-Álvarez and I. Esteve, "Confocal Laser Scanning Microscopy as a Tool to Determine Cyanobacteria Biomass in Microbial Mats," Journal of Microscopy, Vol. 204, No. 3, 2001, pp. 258-262. doi:10.1046/j.1365-2818.2001.00951.x

[37] C. A. Popovich and J. E. Marcovecchio, "Spatial Variability of Phytoplankton and Environmental Factors in a Temperate Estuary of South América (Atlantic Coast, Argentina)," Continental Shelf Research, Vol. 28, No. 2, 2008, pp. 236-244. doi:10.1016/j.csr.2007.08.001

[38] V. N. de Jonge and J. E. E. van Veusekom, "Contribution of Resuspended Microphytobenthos to Total Phytoplankton in the Ems Estuary and Its Possible Role for Grazers," Netherlands Journal of Sea Research, Vol. 30, 1992, pp. 91-105. doi:10.1016/0077-7579(92)90049-K

[39] J. L. Pinckney, H. W. Paerl and B. M. Bebout, "Salinity Control of Benthic Microbial Mat Community Production in a Bahamian Hypersaline Lagoon," Journal of Experimental Marine Biology and Ecology, Vol. 187, No. 2, 1995, pp. 223-237. doi:10.1016/0022-0981(94)00185-G

[40] J. Seckbach, P. G. Eriksson, M. M. Walsh, A. Oren and J. Chela-Flores, "Summary and Conclusions," In: J. Seckbach and A. Oren, Eds., Microbial Mats: Modern and
Ancient Microorganisms in Stratified Systems, Springer, Dordrecht, 2010, pp. 585-590.

doi:10.1007/978-90-481-3799-2 30

[41] D. G. Cuadrado, N. B. Carmona and C. N. Bournod, "Mineral Precipitation on Modern Siliciclastic Tidal Flats Colonized by Microbial Mats," Sedimentary Geology, Vol. 271-272, pp. 58-66. doi:10.1016/j.sedgeo.2012.06.005

[42] F. E. Anderson and B. A. Howell, "Dewatering of an Unvegetated Muddy Tidal Flat during Exposure-Desiccation or Drainage?" Estuaries, Vol. 6, No. 3, 1984, pp. 225-232. doi: $10.2307 / 1352142$

[43] W. Admiraal, "The Ecology of Estuarine Sediment-Inhabiting Diatoms," Progress in Phycological Research, Vol. 3, 1984, pp. 269-322.

[44] J. L. Pinckney, "Development of an Irradiance-Based Ecophysiological Model for Intertidal Benthic Microalgal Production," In: W. Krumbein, D. Paterson and L. Stal, Eds., Biostabilization of Sediments, Universität Oldenburg, Oldenburg, 1994, pp. 55-83.

[45] W. E. Krumbein, "Stromatolites-The Challenge of a Term in Space and Time," Precambrian Research, Vol. 20, No. 2-4, 1983, pp. 493-531. doi:10.1016/0301-9268(83)90087-6

[46] H. Beraldi-Campesi and F. García-Pichel, "The Biogenicity of Modern Terrestrial Roll-Up Structures and Its Significance for Ancient Life on Land," Geobiology, Vol. 9, No. 1, 2011, pp. 10-23. doi:10.1111/j.1472-4669.2010.00258.x 